„Przekłady Literatur Słowiańskich”. T. 11, cz. 1, s. 1-18

ISSN 2353-9763 (wersja elektroniczna)

DOI https://doi.org/10.31261/PLS.2021.11.01.04

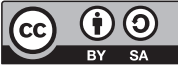

\title{
Under the Winged Sign of "Albatross": Translations of Poe and Whitman and the Development of Serbian Avant-garde
}

Pod skrzydlatym znakiem „Albatrosa”: tłumaczenia Poego i Whitmana

a rozwój serbskiej awangardy

\section{Bojana Aćamović}

iD https://orcid.org/0000-0001-6926-3667

THE INSTITUTE FOR LITERATURE AND ART, BELGRADE bojana.acamovic@gmail.com

Date of application: 29.12.2020 ～Date of acceptance: 25.02.2021

\begin{abstract}
The paper aims to examine Serbian translations of Whitman and Poe published by the representatives of the 1920s avant-garde movements and to point to the place of these translations in the context of the developing Serbian modernism. A special focus is on the book series "Albatross", a short-lived but important project of Belgrade avant-gardists, which significantly influenced the course of Serbian literature.

KEYWORDS | translation, Serbian literature, Edgar Allan Poe, Walt Whitman, Serbian avant-garde, "Albatross" Series
\end{abstract}




\section{Introduction: Translation in Modernism}

Modernism in its various forms, including the more experimental, avant-garde movements, developed as an international phenomenon, with authors, works and ideas traveling, physically and metaphorically, across countries and continents. The vibrant intercultural exchange relied to a considerable extent on translation, which was both a means of introducing wider readership to a particular foreign author and a way of introducing new poetic devices into the target culture and thus expanding the variety of its literary production. Yao argues that translation "constituted an integral part of the Modernist program of cultural renewal" serving as "a specific compositional practice by which different writers sought solutions to the various problems and issues that have come to be understood as the primary thematic concerns of Modernism". ${ }^{1}$ On a broader cultural level, translation practices reflected the current trends in reading and writing, preferences for certain authors or genres, as well as the inter-national relations.

Although long overlooked, the place of translation in modernism has drawn more attention in recent decades, with scholars considering it from both linguistic and cultural perspectives. Pointing to a "transnational turn" in modernism studies, Mao and Walkowitz note three groups of scholarly works, one of which is the "scholarship that argues for the centrality of transnational circulation and translation in the production of modernist art". However, in the case of Serbian, or Yugoslav modernism, there still seems to be many unexplored topics concerning translations and their place in the overall literary and cultural development. This applies to studying specific linguistic or literary aspects of translations, and especially to considering translation in the sociocultural context of the time, which can provide a valuable insight into the transnational literary connections.

Throughout the nineteenth and the beginning of the twentieth centuries, translations constituted a considerable part of Serbian literary production. The reception of foreign authors, however, was conditioned by two important factors, the first of which was the foreign language competence. At the time, the predominant foreign languages in the Serbo-Croatian linguistic area were German and French, ${ }^{3}$ with something of a cultural shift occurring at the turn

1 S. Yao, 2002: Translation and the Languages of Modernism: Gender, Politics, Language. Palgrave Macmillan, p. 6.

2 D. Mao, R. Walkowitz, 2008: The New Modernist Studies. "PMLA" 123 (3), p. 739.

3 German was mostly studied in the (former) Austro-Hungarian territories (Croatia, Bosnia and Herzegovina, Vojvodina). The connection to the French culture was reinforced during World War I, with a number of young Serbian authors emigrating to Paris. 
of the twentieth century, when the generation of "the Moderns" ("Moderna") appeared on the scene. As Bašić notes,

[t]he generation before had been brought up under a predominantly German cultural influence against which they had rebelled in a passionate, embattled and finally successful attempt to re-establish a national literary language and literature. "The Moderns" took this achievement for granted and turned again towards Europe, only this time more consciously towards French and English models. ${ }^{4}$

Although the interest in the English language and culture was gradually increasing, in the first decades of the twentieth century the number of people with a solid command of English was still comparatively small.

The second factor is related to the previous one and concerns the availability of printed publications. Students and scholars who traveled to European cities for longer or shorter stays would return with books and magazines in the language of the visited country. English and American authors were hence often read in and subsequently translated from their French or German translations. ${ }^{5}$ It could also happen that a particular work was in its original language but published as an unauthorized reprint or in a magazine featuring only excerpts from novels or a selection of poems. This could account for some of the errors in the Serbo-Croatian translations, and probably also for the choice of the translated texts or authors.

\section{The "Albatross" Book Series}

In 1921, as part of the postwar efforts to revitalize the literary scene, two Serbian authors, Stanislav Vinaver and Todor Manojlović, started a new book series "Albatross" (Biblioteka "Albatros"), ${ }^{6}$ published by a Belgrade bookshop owned by Mitra Stefanović ("Sveslovenska knjižarnica M. J. Stefanovića i druga"). The series eventually came to include only five titles (of the originally planned at least twenty), and was discontinued in $1922 .^{7}$ Although short-lived and comprising

4 S. Bašić, 1966: Edgar Allan Poe in Croatian and Serbian Literature. "Studia Romanica et Anglica Zagrabiensia", 21-22, p. 307.

5 That translations from English were something of an exception is also indicated by the inscription "translated from English" frequently found underneath the texts.

6 The name references to Baudelaire's "Albatross" (see T. Manojlović, 1987: Osnove i razvoj moderne poezije. Beograd, "Filip Višnjić," p. 305).

7 According to Vinaver, the discontinuation occurred not because of poor sale figures, but owing to "the unexpected bad luck with the printing shop". (S. Vinaver, 2012b: Rastko Petrović, lelujav lik sa freske. In: S. Vinaver: Odbrana pesništva. G. Tešić, ed. Beograd, Službeni glasnik, p. 311.) This is where Vinaver's and Manojlovićs's statements 
a small number of books, the series is now known as one of the most significant Serbian avant-garde projects, as it launched some of the most eminent works and authors of this time.

A publicity leaflet promoting the "Albatross" editions, and also functioning as a literary manifesto, announced that the aim and ideal of the series introduced "under the winged sign of Albatross" was "nurturing and spreading the culture of spirit" and fostering the readers' interest in literature, arts and spiritual matters. ${ }^{8}$ This was to be achieved through a selection of works that would not offer "simple, superficial entertainment" nor "sparse or specialized didactic", but would be "the works of intuition". 'The editors' ambitious plan aimed to include various genres-novels, short stories, dramatic poems, philosophical essays, aphorisms, diaries, biographies, studies in aesthetics and history-the only criterion being a somewhat vague notion that these "works of intuition" should display "the whole man and whole soul" and address "the man and the soul as such". "The series was to feature "our latest literature, the works of our youngest writers, who in less than two years managed to give our literary life a new direction and wonderfully accelerated new rhythm", as well as "the masterpieces of world literature which correspond to our movement and our aims and which we will, understandably, introduce in new, modern and artistic translations".11 As Manojlović later pointed out, the intention was to publish "all that was interesting in our postwar literature, as well as the best works of world-renowned authors, naturally selected according to the "postwar criterion"". ${ }^{12}$ To illustrate this intention, the leaflet presents an extensive list of both domestic and foreign authors, and as regards the latter, included are the representatives of French (Apollinaire, Barbey d'Aurevilly, Balzac, Baudelaire, Villiers de l'Isle-Adam, Gide, Suarès, Flaubert), Italian (Machiavelli), German (E. T. A. Hoffmann), Russian (Zaitsev, Sologub), British (H. G. Wells, R. L. Stevenson, W. Pater, G. K. Chesterton) and American literature (W. Whitman and E. A. Poe). Although it seems more of a draft than a carefully thought-out plan and although it was obviously far too ambitious for the available means, this list testifies to the breadth of the Serbian avant-gardists' interests and their acquaintance with the contemporary tendencies across Europe.

diverge as the latter claims that finances were indeed the reason they had to abandon the project.

8 S. Vinaver, 2012a: Čardak ni na nebu ni na zemlji. Beograd, Službeni glasnik, p. 36. All translations of the citations from works in Serbian and Croatian are provided by the author of this paper.

9 Ibidem.

10 Ibidem.

11 Ibidem.

12 T. Manojlović, 1987: Osnove..., p. 305. 
Little of the envisaged program was realized, but the few published works significantly influenced the development of Serbian literature. Of the five books that appeared in the series, the first four were by domestic authors-Dnevnik o Čarnojeviću (The Journal of Čarnojević) by Miloš Crnjanski (1921), Gromobran svemira (The Lightning Rod of the Universe) by Stanislav Vinaver (1921), Burleska Gospodina Peruna Boga Groma (The Burlesque of Lord Perun, the God of Thunder) by Rastko Petrović (1921) and Lunar by Josip Kulundžić (1921/22); the fifth was a translation, a selection of Edgar Allan Poe's poetry and prose entitled Knjiga tajanstva i mašte (A Book of Mystery and Imagination) translated by Svetislav Stefanović. ${ }^{13}$

The scholars analyzing the "Albatross" Series mostly focus on the published works, especially the first three, which indeed hold an eminent place in the history of Serbian literature. Maria Dąbrowska-Partyka centers her discussion entirely around the works by Crnjanski, Vinaver and Petrović, completely disregarding both Kulundžićs's novel and Stefanovićs translation of Poe. ${ }^{14} \mathrm{~A}$ broader picture is offered by Gojko Tešić, who quite importantly observes that the list of authors on the publicity leaflet suggests the editors' striving towards "a reconstruction / reinterpretation of tradition, or even establishment of a continuity of modern spirit in literature and art", which makes the whole endeavor "an attempt of constituting a tradition of new spirit and new rhythm (Baudelaire, Poe, Whitman, Hoffmann, Machiavelli, Flaubert, Gide, Apollinaire, etc.)". ${ }^{15}$ The avant-gardists did attempt to introduce the new and modern, but that did not mean a complete disregard for the eminent predecessors, carefully selected according to "the postwar criterion".

The list of potential "Albatross" authors problematizes some common assumptions concerning the poetics of avant-garde and modernism. Whereas among the domestic names were solely young authors, most still unrecognized in literary circles, the list of foreign authors includes many of the previous century, which confirms that for the decisively anti-traditionalist avant-garde,

13 A longer announcement contains short descriptions of additional four books that were, presumably, in preparation for print-Osnovi i razvoj moderne poezije (Foundations and Development of Modern Poetry) by T. Manojlović, Antologija najnovije lirike (An Anthology of the Newest Lyric Poetry), ed. by S. Stefanović, T. Manojlović and S. Vinaver, Dramske gatke (Dramatic Fairytales) by R. Mladenović and a translation of Boccaccio's Decameron. Some of these appeared some years (or decades) later, but not within the "Albatross" Series. See S. Vinaver, 2012a: Čardak..., pp. 32-35.

14 See M. Dombrovska-Partika, 1997: Biblioteka ALBATROS i Beogradska književna zajednica ALPHA - reč je o jedinstvu suprotnosti. N. Bajić, D. Đumić, trans. "Književna kritika", 26, pp. 110-122.

15 G. Tešić, 2005: "Albatrosova" najava bure. In: G. Tešić: Otkrovenje srpske avangarde. Beograd, IKUM, p. 140. 
the break with the tradition did not mean an absolute break with the past. Disowning the precursors and asserting that the modern is independent of any influences from the past primarily implied the rejection of the canonical figures. Instead of relying on what is traditionally accepted, the encouragement for experimental endeavors is sought in works considered more daring, even if written in the past century. As Cutler observed, "while the aesthetic avant-garde courted an absolute new by means of shock, provocation and destruction, ideological forces from a considerably larger field of nineteenth-century discourse underwrote the entire enterprise". 16 The nineteenth-century authors like Poe or Whitman announced the poetic innovations of the following decades and thus were rightfully recognized as the proto-modernists.

Apart from this, the "Albatross" choice of foreign authors disproves the belief that modernist literature is predominantly elitist and averse to the popular, and by implication genre literature. The editors' statement that they shun "simple, superficial entertainment" and aim for the "works of intuition" implies that all the mentioned authors, including those of mystery, fantasy, gothic horror and detective fiction, satisfy this criterion. The incorporation of genre fiction in the "Albatross" publishing plan undermines the generally accepted divide between the high modernist and popular literature and attests to the avant-gardists' openness for the authors of an extraordinary imagination and ability to step out of the established conventions.

\section{The Mystery and Imagination of Edgar Allan Poe}

The Book of Mystery and Imagination (Knjiga tajanstva i mašte), with the selected poems and short stories by Edgar Allan Poe, appeared in 1922 as the fifth and, as it turned out, the last book in the "Albatross" Series. The title points to Poe's posthumously compiled selection of short stories Tales of Mystery and Imagination, but also indicates that the Serbian edition is not limited to prose fictionincluded are two poems, "The Raven" and "Annabel Lee", as well as the stories "A Descent into the Maelström" "The Facts in the Case of M. Valdemar", "William Wilson", "Morella" "Ligeia", "The Fall of the House of Usher", "Silence-A Fable" and "Shadow-A Parable". All of these had appeared in Serbo-Croatian translations before, some of them more than once, in different publications (mostly periodicals) and translated by different translators.

Although it is not explicitly stated, the selection was most likely made by the translator, Svetislav Stefanović. A physician by profession, Stefanović was also

16 E. S. Cutler, 2003: Recovering the New. University of New Hampshire, p. 21. 
a poet, literary critic, and one of the rare Serbian intellectuals with an excellent command of the English language. By the time the "Albatross" edition of Poe appeared, Stefanović had already been established as an apt translator of English poetry, having translated Shakespeare, a number of distinguished nineteenth-century British poets, as well as Poe and Whitman. His translations of "The Raven" and "Annabel Lee" (along with five other Poe's poems) were published in 1903 by a publisher from Mostar, in a volume containing Stefanovićs own poetry and a selection of his translations; ${ }^{17}$ both translations were considerably modified for the "Albatross" edition. In 1902, Stefanovićs translation of "A Descent into the Maelström" and "The Facts in the Case of M. Valdemar" appeared in a separate volume issued by the same Mostar publisher. This booklet also included Stefanovićs foreword, aiming to arouse the interest in the American author, "who is in our culture little known or completely unknown, although some judge him one of the greatest foreign minds." ${ }^{18}$ The foreword introduces Poe not through biographical facts, but through his works and artistic achievements, and Stefanović primarily focuses on the "psychological matters" leaving aside "the well-known detective and purely fantastic stories." ${ }^{19}$ Stefanović sees Poe as an author who dives deep into the human soul to discover something new and previously unknown, an author who established a "psychology of dying, of death" and whose characters face death fully conscious. The foreword emphasizes Poe's mysticism, his fondness of the fantastic, and his representation of the human soul prevailing over the decayed body. Stefanović addresses the claims about Poe's "sick imagination", asserting the difficulty of delineating the boundaries between a sick and a healthy imagination, and suggests that a distinction between a productive and an unproductive imagination would be more to the point. Poe's poetics is further contrasted to the currently predominant "shallow realism", which Stefanović dismisses as too limited, concluding that the Serbian audience would benefit from reading this author, "who showed, as few had done, that art is not and must not be only a drawing, an abbreviation of life [...]", since art "can and must follow the human mind to and beyond its highest, most daring flights" ${ }^{20}$

That Stefanović was an authority on literature in English is confirmed by the forewords to two later Serbian translations of Poe's works, The Black Cat and

17 See S. Stefanović, 1903: Pesme originalne i prevedene. Mostar, Paher i Kisić. Apart from the seven poems by Poe, the volume contains poetry of Byron, Shelley, Moore, Rossetti, and Shakespeare. In 1904 and 1905, Stefanović published new volumes of his original and translated poems, among which was another Poe's poem.

18 S. Stefanović, 1902: Nekoliko reči o piscu. In: E. A. Po: Dve pripovetke. S. Stefanović, trans. Mostar, Paher i Kisić, p. 3.

19 Ibidem.

20 Ibidem, p. 9. 
Other Tales (1920), translated by Branko Lazarević, and The Narrative of Arthur Gordon Pym (1925), translated by Isidora Sekulić. Both start with the concluding sentences from Stefanovićs 1902 essay, somewhat paraphrased and abridged, but preserving the main ideas-both refer to the "realism content with the romanticism of the common reality", a writer who showed that "art is not only a drawing, an abbreviation of life" and art which "can and must follow human mind to and beyond its highest and most daring flights." ${ }^{21}$ Neither mentions Stefanović as the author of these words. Apart from the ethics of the 1920s publishing practices, these two forewords show that Stefanovićs evaluation of Poe as an author opposed to the literature of realism was commonly accepted among the Serbian critics and translators as something that should recommend the American author to the readers.

The "Albatross" edition of Poe starts with an essay by the series editor, Stanislav Vinaver. From the first sentences, Vinaver introduces a very personal note intimating that he has "always wanted to meet Edgar Poe" and wondering what this encounter would look like and where it could take place. ${ }^{22}$ Through a series of questions and ruminations on magnetic forces, Poe's perfect but unfinished worlds, and fictional characters surpassing "our naïve culture", Vinaver composes an essay which, as Bašić observes, expresses his own "subjective, emotional experience of Poe" so that in the end we learn almost nothing about Poe and his work. ${ }^{23}$ Rather than a typical foreword, Vinaver's text is an expressionist essay inspired by Poe and as such testifying to the impact Poe's writing had on the imagination of Serbian avant-gardists.

Aside from Vinaver's meditations on Poe, this essay offers a few concrete facts, as well-that Vinaver first read Poe in French translation and learned about his work through Baudelaire, Mallarmé, as well as "the Poles, Russians, Germans", before he was finally able to read Poe in English. ${ }^{24}$ Vinaver shows special reverence for this translation asserting that

Poe's prose contains in itself organic nervous centers and sensitive electric buttons to be pressed suddenly, fatally. Closed, sealed with the music of the waves, this cannot always be seen in the original [...] A congenial translator discerns, senses those spots and they, illuminated by another language, shine through with a more fatal, prophetic shine. ${ }^{25}$

21 See E. Po, 1920: Crna mačka i druge pripovetke. B. Lazarević, trans. Beograd, Narodno delo, p. 2 and E. A. Po, 1925: Avanture Gordona Pima. I. Sekulić, trans. Beograd, Savremena biblioteka, p. 7. Both forewords are unsigned.

22 E. A. Po, 1922: Knjiga tajanstva i mašte. Beograd, Sveslovenska knjižarnica, p. 7.

23 S. Bašić, 1969: E. A. Poe u hrvatskoj i srpskoj književnosti: doktorska disertacija. Zagreb, Filozofski fakultet, pp. 151-152.

24 E. A. Po, 1922: Knjiga tajanstva i mašte..., p. 8.

25 Ibidem, p. 9. 
Stefanovićs translation indicates that "something oceanic-Poesque has been suffered also in Serbian: some love, some power of ascent by the paths of our languages to Edgar Poe". ${ }^{26}$

The "Albatross" edition of Poe was reviewed by Rastko Petrović the same year in the newspaper Vreme. Petrović begins his review discussing the translations he and his generation grew up on and compares the early Serbian editions of Shakespeare, Boccaccio and Schiller, the language of which was "very serious, archaic, hardly intelligible for its strain to express more and more concisely than it was expected ever before", to the editions of Paher and Kisić in Mostar, rendered in a language that was far more comprehensible, making everything "closer and more intimate, more humane, and since the strain of the language and expression was abandoned, the only thing left was the strain of imagination". ${ }^{27}$ Petrović particularly refers to Stefanovićs translations of Poe, "the great alcoholic, invalid, and vagabond of the New World", who knew "the mechanics of fear, decay and horror; the logics of madness and the right way to the nothingness with no return", but who also reached a spiritual purity and unprecedented levels of symbolization. ${ }^{28}$ After pointing to some biographical facts, Petrović turns to the most distinct themes of Poe's poetics-the horrible mystery of being, the constant struggle of man to conquer the threatening forces, as well as Poe's deductive method of starting from a strange fact and continuing to the infinity. The Serbian author concludes that, apart from Hoffmann, Poe might be the only writer who dealt with so many mysteries in his work.

Other representatives of Serbian modernism responded to similar aspects of Poe's poetics. Isidora Sekulić, who translated The Narrative of Arthur Gordon Pym of Nantucket, included Poe among the "poets of the abyss", poètes maudits, who "accursed tirelessly pass through the conscious, subconscious and superconscious realities" ${ }^{29}$ While Poe may have been a poète maudit, he was readily accepted both by the avant-garde and the more conservative circles of the Serbian literati. The fact that he had reached Europe through Baudelaire secured him affections of critics such as Marko Car and Bogdan Popović, who valued symbolism, stood for poetic conventions and disapproved of the avant-garde experiments. As for the avant-gardists, Poe was welcomed not only for his exploration of the mysterious and the otherworldly, but also for his modernity. This is a feature Boško Tokin emphasized in "U. S. A. = Poe, Whitman, Chaplin", presenting Poe as one of the three figures that "constitute and create the spiritual

26 Ibidem.

27 R. Petrović, 1922: Knjiga tajanstva i mašte. "Vreme", 2 (364), p. 5.

28 Ibidem.

29 I. Sekulić, 1954: Jedan od pesnika ponora: Edgar Alan Po. In: E. A. Po: Odabrana dela. Z. Mišić, ed. Beograd, Novo pokolenje, p. 5. 
atmosphere of the innermost America". ${ }^{30}$ In Tokin's view, Poe produced "a new type of man" and discovered "new relations of man to man, to objects, to animals, and to cosmos"." The mysterious, the eerie and the mad in Poe's work is what made him "a forerunner of expressionism", as he was "the first creator of that modern sense of the surreal which takes us to the other side of grammar, formulas, rules and all possible stiff logics" ${ }^{32}$ As seen from Tokin's, as well as the essays by other abovementioned authors, Poe's poems and tales were found intriguing for their exploration of the human psyche, of the unconscious and subconscious and of the borderline states between life and death, all of which were being explored in the art and literature of that time.

\section{Whitman's cosmos in free verse}

The "Albatross" Series did not survive long enough to include the translation of Whitman and, although the publication of his poetry was planned, today we do not have any precise information on this book. Was it to be a separate volume of Whitman's poetry? Or an anthology of poems by various authors? What can be taken for certain is that the translator of Whitman's poetry would have been the same person who translated Poe, Svetislav Stefanović. Not only was Stefanović a recognized translator of English poetry and closely collaborating with the "Albatross" editors, but he had already published translations of Whitman's poems.

In 1920, Stefanovićs five translations of Whitman appeared in three Belgrade periodicals_ "Pensive on Her Dead Gazing" in Misao, "Pioneers! O Pioneers!" in the Easter number of Republika, and lastly "Dirge for Two Veterans", "For You O Democracy" and "When Lilacs Last in the Dooryard Bloom'd" (section 16) in Srpski književni glasnik. All these were reprinted in 1923, in an anthology Iz novije engleske lirike (From Newer English Lyric Poetry), also selected and translated by Stefanović. ${ }^{33}$ The five poems were translated from the original language, but not according to the original, American edition. As indicated in the biographical note at the end of the 1923 volume, the source was "the selected

30 B. Tokin, 1920: U. S. A. = Poe, Whitman, Chaplin. "Progres", 1 (128), p. 2.

31 Ibidem.

32 Ibidem, pp. 2-3.

33 Apart from Whitman, the collection contains poems by E. B. Browning, J. Keats, A. Tennyson, D. G. Rossetti, A. G. Swinburne, O. Wilde, and E. A. Poe. Of Poe's poems, here included are the translations of "The Raven", "Annabel Lee", "The Conqueror Worm", "A Dream Within a Dream", "The Sleeper", "The Haunted Palace", "Ualalume” and "Eldorado". 
poetry and study by W. Rossetti", that is the British edition of Whitman's poetry, which William Michael Rossetti compiled following the fourth (1867) edition of Leaves of Grass and published in 1868. This is confirmed by the titles of the poems in Stefanovićs translation, which follow Rossetti's versions and not the original titles-in Rossetti's edition, "Pensive on Her Dead Gazing" becomes "Mother of All" (in Stefanović: "Mati svega"), "When Lilacs Last..." becomes "President Lincoln’s Funeral Hymn" (Stefanović: "Iz himne povodom smrti A. Linkolna"), and "For You O Democracy" (in 1867 titled "Song") becomes "Love of Comrades" (Stefanović: "Ljubav drugara"). The British edition contains about half of the 1867 edition of Leaves, and as Rossetti himself states, he made the selection with the aim "first, to omit entirely every poem which could with any tolerable fairness be deemed offensive to the feelings of morals or propriety in this peculiarly nervous age; and, second, to include every remaining poem which appeared to [him] of conspicuous beauty or interest". ${ }^{34}$ Whitman later referred to this edition as "the horrible dismemberment of my book." ${ }^{35}$ This was, however, the edition Stefanović had at his disposal and, judging by the overall Serbian reception of Whitman's work, it did not significantly distort the image of the American poet.

In the preface to the 1923 volume, Stefanović intimates:

To me, a sojourn in English poetry is always a great liberation. Liberation from me myself, from the life of the environment in which I live no matter how artistic and elevated it aims to be; and above all, liberation from the bonds, chains and patterns of the art itself in general and of our art, which are imposed on it by a routine, school, academy. ${ }^{36}$

Such liberation is embodied in Whitman's free verse, as a major innovation this poet brought to the modern poetry. Whitman's non-metrical, non-rhymed lines of irregular length provoked many discussions and polemics, as well as posed new challenges with regard to translation. Although intended to encourage liberation from poetic conventions and bring poetry closer to the natural rhythm of speech, Whitman's free-verse poems confused both his readers and translators for the simple reason that they were too prose-like. This was also a feature that repelled some Serbian critics and caused them to dispute Whitman's status of a poet. Bogdan Popović as the most vociferous of Whitman's

34 W. M. Rossetti, 1868: Prefatory Notice. In: W. M. Rossetti, ed.: Poems by Walt Whitman. London, J. C. Hotten, p. 20.

35 W. Whitman, 1961: Correspondence Vol. 2 (1868-1875). E. H. Miller, ed. New York, New York UP, p. 133.

36 S. Stefanović, 1923: Iz novije engleske lirike. S. Stefanović, ed., trans. Beograd, Napredak, p. vii. 
Serbian detractors claimed that his poems (or rather, "poems", as Popović designates them) were "mostly democratic newspaper articles written in rhetorical prose [which] become verses only because they have been printed as verses".

Whitman's admirers had difficulties in grasping his free verse, as well. Some of the prewar translations by the Young Bosnia circle show different approaches in presenting these uncommonly long lines. Laid out in the columns of Bosanska vila, side by side with short fiction and each verse broken into several lines for the lack of horizontal space, Whitman's poems indeed come across as prose pieces composed of a number of shorter paragraphs. This impression was additionally strengthened by the peculiar indentation in some of the translations. Borivoje Jevtić in his rendering of the part 21 of "Song of Myself" joins together two or three separate lines into even longer ones:

\begin{tabular}{l|l|}
$\begin{array}{l}\text { I am the poet of the Body and I am the poet } \\
\text { of the Soul, } \\
\begin{array}{l}\text { The pleasures of heaven are with me and } \\
\text { the pains of hell are with me, }\end{array}\end{array}$ & $\begin{array}{l}\text { Ja sam pesnik tela i ja sam pesnik duše; ne- } \\
\text { beska blaženstva su kod mene, i kod mene su } \\
\text { muke paklene. }\end{array}$ \\
\hline
\end{tabular}

Mitra Moračina in her translations of "Who Learns My Lesson Complete" and "On the Beach at Night Alone" goes a step further in "prosing" Whitman by failing to indent new lines and thus turning stanzas into prose paragraphs:

A vast similitude interlocks all,

All spheres, grown, ungrown, small, large, suns, moons, planets,

All distances of place however wide,

All distances of time, all inanimate forms,

All souls, all living bodies though they be ever so different, or in different worlds, All gaseous, watery, vegetable, mineral processes, the fishes, the brutes,

All nations, colors, barbarisms, civilizations, languages,

All identities that have existed or may exist on this globe, or any globe,
Ogromna sličnost sve sklapa jedno u drugo; sve svere, odraslo i neodraslo, malo, veliko; sva sunca, mjesece, biljke; sve udaljenosti mjesta ma kako daleko bila; sve daljine vremena, sve bezživotne forme, sve duše, sva živa tijela makako bila različita i ma kako u različitim svijetovima. Svi gasovi, vode, biljke, mineralni procesi, životinje; svi narodi, boje, varvarstva, civilizacije, jezici; sve identičnosti što su eksistirale ili će možda eksistirati na ovom zemaljskom globusu; svi životi, sve smrti, sve iz prošlosti, sadašnjosti, budućnosti. Ova ogromna sličnost

37 B. Popović, 1921: Prevodi u stihu i sliku. "Srpski književni glasnik", 2 (2), p. 132.

38 W. Whitman, 2004: Leaves of Grass. K. Karbiener, ed. New York, Barnes \& Noble, 210.

39 U. Uitmen, 1912: Iz "Pesme o meni samom”. B. Jevtić, trans. "Bosanska vila”, 27 (1718), p. 237. 
All lives and deaths, all of the past, present, future,

This vast similitude spans them, and always has spann'd,

And shall forever span them and compactly hold and enclose them. ${ }^{40}$

The blurring of the boundaries between poetry and prose provoked discussions on the nature and necessity of formal restrictions. Svetislav Stefanović took an active part in discussing these topics, which he specifically addresses in the essays "Stih ili pesma?" (“A Verse or a Poem?"), "Više slobode stiha!" ("More Freedom of the Verse!") and "Ritam i emocija" ("Rhythm and Emotion"). ${ }^{42}$ Arguing that lines should primarily follow the poet's idea and inspiration, and not some preset rules, Stefanović references to Whitman as a free verse poet "who despised all poetics, and yet left the humankind some of the most glorious poems". ${ }^{43}$ Stefanović continued his defense of free verse during the 1920s, still taking Whitman as an example of a successful use of this poetic form. What he defended in his essays, the Serbian author illustrated through his translations of Whitman, in which he strived to faithfully convey both the semantic content and the original demarcation of lines. Babić notes that Stefanović is more reliable than the previous translators, both "lexically and metrically", managing to find "a well-chosen expression which suits well Whitman's exalted cosmic ideas". In his translations, Stefanović thus promoted both the thematic content and formal innovations of Whitman's poetry, primarily the free verse.

Whitman's approach to versification was one of the reasons why his reception followed a road somewhat rockier than Poe's. While Poe was warmly welcomed as a representative of l'art pour l'art, as well as Baudelaire's and Mallarmé's American favorite, Whitman wrote the kind of poetry that was too unorthodox to be broadly accepted or even recognized as poetry. Nevertheless, the more the traditionalist circles attacked him, the more the avant-garde ones embraced him. In 1921, Boško Tokin published the article "Four Beginnings of Modern Poetry-Baudelaire, Rimbaud, Whitman, Nietzsche", written on the occasion of Baudelaire's centennial but largely focusing on free verse and its place in modern poetry. After identifying Baudelaire as a great predecessor of symbolism

40 W. Whitman, 2004: Leaves of Grass..., pp. 413-414.

41 V. Uajtmen, 1913: Sam na obali noću. M. Moračina, trans. "Bosanska vila”, 28 (13-14), p. 190.

42 All three appeared in "Bosanska vila", in 1912 and 1913, which was the time when this magazine published the bulk of the pr ewar Whitman translations.

43 S. Stefanović, 1912: Stih ili pesma. "Bosanska vila", 27 (13-14), p. 186.

44 Lj. Babić, 1976: Walt Whitman in Yugoslavia. "Acta Neophilologica”, 9, p. 42. 
and modernism and designating both him and Poe "the last Goths", 45 Tokin proceeds to discuss the modern poetry in free verse. Referring to specific poems (among them Laforgue's French translations of Whitman), Tokin stresses that this form has been widely recognized as legitimate for some decades. Without any attempt to minimize the significance of symbolism, to which he refers as "the poetry of freedom, poetry expressing connections, affinities between the man and the deity" and "the lyric and musical poetry of cosmos", Tokin avers that "Whitman's poetry of cosmos is still more powerful, more natural". ${ }^{46}$ While stressing his importance as a free-verse poet, Tokin particularly underscores that Whitman is a representative of modernity and modernist poetics as a poet who himself is "a cosmos".

Tokin referred to Whitman's cosmism in the texts he published as the editor of the magazine Zenit, as well. He turns to Whitman while discussing the dynamics of the new art and new spirit, the aim of which is establishing "the cosmic, expressionist art of Zenith" and describes the American poet as a "gigantic barbaro-cosmos" and a representative of a spiritual line reaching to the expressionists. ${ }^{47}$ Tokin was not the only one placing Whitman among the expressionists, as Vinaver did the same in his "Manifesto of the Expressionist School" (the introductory text of his Gromobran svemira) arguing that Whitman is one of those who "take from nature more than it gives in one impression" and thus provide an "expression", a new unity which surpasses the rhythm of nature. ${ }^{48}$ Like Poe, although for somewhat different reasons, Whitman was recognized as a proto-modernist, a forerunner of expressionism, and as such placed on the line of modernity which was to culminate in the age of modernism.

\section{Conclusion}

Svetislav Stefanović ended one of his forewords with the observation that translations, although never completely faithful, are necessary "for the sake of one's own and the general literary culture, without which [...] there can be no real work in literature". ${ }^{49}$ The Serbian translations of E. A. Poe and W. Whitman

45 B. Tokin, 1921a: Četiri početka moderne poezije-Baudelaire, Rimbaud, Whitman, Nietzsche. "Svetski pregled", 1 (3), p. 13.

46 Ibidem.

47 B. Tokin, 1921b: Mladi reakcionari i novi duh. "Zenit", 1 (2), p. 4.

48 S. Vinaver, 1921: Manifest ekspresionističke škole. In: S. Vinaver: Gromobran svemira. Beograd, Sveslovenska knjižarnica, p. 17.

49 S. Stefanović, 1923: Iz novije engleske lirike. S. Stefanović, ed., trans. Beograd, Napredak, p. xi. 
published in the 1920s can be said to have inspired some "real work in literature", considering the impact they had on the interwar literary scene by affecting the imagination of the Serbian modernist writers and poets. That Poe and Whitman were intended to appear in the new "Albatross" Series comes as no surprise since they were a constant presence in the minds and writings of the people gathered around this project, the editors as well as the translator. The latter, Svetislav Stefanović, whose interest in English literature resulted in several volumes of translations and some important essays, played a key part in introducing Poe and Whitman to the Serbian readership by translating their works and discussing the poetic innovations they introduced. Quite importantly, his translations were accompanied by essays and articles written by other representatives of Serbian modernism, who by pointing to specific thematic and formal aspects of these works also revealed which features were of particular interest to them as writers.

A sustained interest in Poe and Whitman, as well as in the other representatives of modernist tendencies planned for the "Albatross" Series, indicates that Serbian modernism was developing in dialogue with the select foreign authors and was open to the ideas and formal features they introduced. Translating these authors was a way not only of presenting them to the Serbian audience, but also of delving deeper into their poetics for the sake of discovering new approaches and new poetic devices. The translators and editors of Whitman's and Poe's works showed a particular interest in those aspects of the American writers' poetics that were close to their own literary preferences, which concerned the formal, thematic and conceptual levels. Poe's mysticism and exploration of the darker side of human psychology and Whitman's call for liberation manifested through his free verse marked them as forerunners of expressionism and encouraged the younger generation of Serbian poets to undertake exploring these topics and to search for new forms of expression. This indicates that one reason for translating the works of authors such as Poe and Whitman was to promote the literary styles and poetics that were considered modern and avant-garde and as such worth being fostered in Serbian literature, as well. On a wider scale, the case of these 1920s translations of Poe and Whitman illustrates the lively intercultural exchange of the interwar period, which often engendered surprising results and which highlights that modernism is essentially a complex multifaceted and multilingual global phenomenon. 


\section{Literature}

Babić Lj., 1976: Walt Whitman in Yugoslavia. "Acta Neophilologica”, 9, pp. 9-58. Bašić S., 1966: Edgar Allan Poe in Croatian and Serbian Literature. "Studia Romanica et Anglica Zagrabiensia: Revue publiée par les Sections romane, italienne et anglaise de la Faculté des Lettres de l'Université de Zagreb", 21-22, pp. 305-319.

Bašić S., 1969: E. A. Poe u hrvatskoj i srpskoj književnosti: doktorska disertacija. Zagreb, Filozofski fakultet.

Cutler E. S., 2003: Recovering the New: Transatlantic Roots of Modernism. University of New Hampshire.

Dombrovska-Partika M., 1997: Biblioteka ALBATROS i Beogradska književna zajednica ALPHA - reč je o jedinstvu suprotnosti. N. Bajić, D. Đumić, trans. “Književna Kritika", 26, pp. 110-122.

Manojlović T., 1987: Osnove i razvoj moderne poezije. Beograd, "Filip Višnjić".

Mao D., Walkowitz R., 2008: The New Modernist Studies. “PMLA”, 123 (3), pp. 737-748.

Petrović R., 1922: Knjiga tajanstva i mašte. "Vreme", 2 (364), p. 5.

Po E., 1920: Crna mačka i druge pripovetke. B. Lazarević, trans. Beograd, Novo delo.

Po E. A., 1922: Knjiga tajanstva i mašte. S. Stefanović, trans. Beograd, Sveslovenska knjižarnica M. J. Stefanovića i druga.

Po E. A., 1925: Avanture Gordona Pima. I. Sekulić, trans. Beograd, Savremena biblioteka.

Popović B., 1921: Prevodi u stihu i sliku. "Srpski književni glasnik", 2 (2), pp. 124139.

Rossetti W. M., 1868: Prefatory Notice. In: W. M. Rossetti, ed.: Poems by Walt Whitman. London, J. C. Hotten, pp. 1-27.

Sekulić I., 1954: Jedan od pesnika ponora: Edgar Alan Po. In: Z. Mišić, ed.: E. A. Po, Odabrana dela. Beograd, Novo pokolenje, pp. 5-12.

Stefanović S., 1902: Nekoliko reči o piscu. In: E. A. Po: Dve pripovetke. S. Stefanović, trans. Mostar, Izdavačka knjižarnica Pahera i Kisića, pp. 3-9.

Stefanović S., 1903: Pesme originalne i prevedene. Mostar, Štamparsko-umjetnički zavod Pahera i Kisića.

Stefanović S., 1912: Stih ili pesma. "Bosanska vila”, 27 (13-14), pp. 185-186.

Stefanović S., 1923: Iz novije engleske lirike. S. Stefanović, ed., trans. Beograd, Napredak.

Tešić G., 2005: „Albatrosova“ najava bure. In: G. Tešić, ed.: Otkrovenje srpske avangarde. Beograd, Institut za književnost i umetnost, pp. 139-147. 
Tokin B., 1920: U. S. A. = Poe, Whitman, Chaplin. "Progres", 1 (128), pp. 2-4.

Tokin B., 1921a: Četiri početka moderne poezije - Baudelaire, Rimbaud, Whitman, Nietzsche. "Svetski pregled", 1 (3), pp. 12-14.

Tokin B., 1921b: Mladi reakcionari i novi duh. "Zenit”, 1 (2), pp. 1-4.

Uajtmen V., 1913: Sam na obali noću. M. Moračina, trans. "Bosanska vila”, 28 (13-14), p. 190.

Uitmen U., 1912: Iz "Pesme o meni samom”. B. Jevtić, trans. "Bosanska vila”, 27 (17-18), p. 237.

Vinaver S., 1921: Manifest ekspresionističke škole. In: S. Vinaver, ed.: Gromobran svemira. Beograd, Sveslovenska knjižarnica M. J. Stefanovića i druga, pp. 3-28.

Vinaver S., 2012a: Čardak ni na nebu ni na zemlji: eseji i kritike o srpskoj književnosti. G. Tešić, ed. Beograd, Službeni glasnik.

Vinaver S., 2012b: Rastko Petrović, lelujav lik sa freske. In: S. Vinaver: Odbrana pesništva. G. Tešić, ed. Beograd, Službeni glasnik, pp. 311-338.

Yao S. G., 2002: Translation and the Languages of Modernism: Gender, Politics, Language. Palgrave Macmillan.

Whitman W., 1961: Correspondence Vol. 2 (1868-1875). E. H. Miller, ed. New York, New York UP.

Whitman W., 2004: Leaves of Grass. K. Karbiener, ed. New York, Barnes \& Noble.

\section{Bojana Aćamović \\ Pod krilatim znamenjem „Albatrosa“: prevodi Poa i Vitmana i razvoj srpske avangarde}

REZIME | Rad razmatra prevodnu recepciju dela E. A. Poa i V. Vitmana u kontekstu razvoja avangardnih tendencija u srpskoj književnosti 1920-ih. Centralni deo istraživanja usmeren je na Biblioteku „Albatros“, u okviru koje se 1922. pojavilo izdanje Poove poezije i proze u prevodu S. Stefanovića, a bilo planirano i objavljivanje Vitmanovog dela. Značaj ovih prevoda ogleda se između ostalog u tome što su poslužili za dalje promovisanje modernističkih tendencija a srpskim književnicima bili inspiracija za nove poetičke eksperimente.

KLJUČNE REČI | prevod, srpska književnost, Edgar Alan Po, Volt Vitman, srpska avangarda, Biblioteka „Albatros“ 


\section{Bojana Aćamović \\ Under the Winged Sign of "Albatross": Translations of Poe and Whitman and the Development of Serbian Avant-garde}

SUMMARY | The paper analyzes the translation reception of the works of E. A. Poe and W. Whitman in the context of the avant-garde tendencies developing in the Serbian literature of the 1920s. The research focuses on the book series "Albatross," within which a book of Poe's poetry and prose appeared in 1922, translated by S. Stefanović, and which was planned to include a translation of Whitman's work, as well. The translations of Whitman and Poe in this period played a significant role in promoting modernist tendencies and inspired Serbian authors to undertake new poetic experiments.

KEYWORDS | translation, Serbian literature, Edgar Allan Poe, Walt Whitman, Serbian avant-garde, "Albatross" Series

BOJANA AĆAMOVIĆ | born in 1985 in Sarajevo, Research Associate at the Institute for Literature and Art in Belgrade; researcher of the English literature and the Anglo-American-Serbian cultural relations. In her doctoral dissertation (defended in 2018), she explored the reception of Walt Whitman's poetry in the Serbian avant-garde literature. Her research centers on the fields of British and American literature (19th century to postmodernism), European avant-garde, and cultural studies. 